\title{
DISKURSUS STUDI HADIS DALAM WACANA ISLAM KONTEMPORER
}

\author{
Dzikri Nirwana \\ Fakultas Ushuluddin IAIN AntasariBanjarmasin \\ E-mail: dzikri.albanjari@yahoo.com
}

\begin{abstract}
In the Islamic discourse, the study of hadith is in demand today. This is because the function of hadith is as a source of Islamic teachings which is a necessity in human life in all circumstances and conditions. Therefore, the proper method of understanding hadith through comprehensive approach both textual and contextual is required. The study of hadith also needs methodology enlightenment and paradigm shift. In this case, modification and adaptation of information and methodology elements by a discipline from other disciplines is a natural thing. This integration of various diciplines is then known as interdisciplinary and multidisciplinary approach. Interdisciplinary approach in the study of hadith which use the traditional Islamic science is also done by a number of contemporary scholars of hadith.
\end{abstract}

Kata kunci: Studi hadis, naqd al-hadits, fiqh al-hadits

\section{Pendahuluan}

Hadis, atau yang biasa dipertukarkan dengan terma sunnah, memiliki definisi yang beragam. Bagi kalangan ahli usul fikih misalnya, hadis atau sunnah adalah segala perkataan, perbuatan dan persetujuan Nabi Muhammad saw. yang berhubungan dengan hukum, selain al-Qur'an. ${ }^{1}$ Sementara dalam versi ahli hadis, hadis mempunyai pengertian yang lebih luas mencakup segala sesuatu yang disandarkan kepada Nabi saw., baik berupa perkataan, perbuatan, persetujuan, penampilan fisik dan budi pekerti, biografi, peperangan, hingga gerak dan diam dalam kondisi jaga dan tidur, serta sesuatu yang disandarkan kepada sahabat dan tabi'în. ${ }^{2}$ Bertolak dari yang disebut terakhir ini, maka

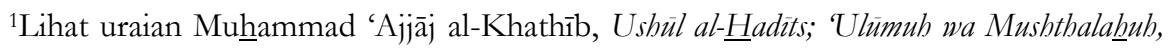
(Beirut: Dār al-Fikr,1989), h. 19.

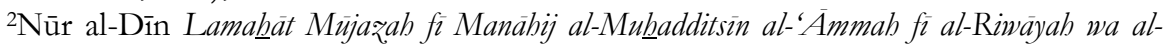
Tashniff, (Damaskus: Dār al-Farfūr, 1999), h. 27. 
wilayah studi hadis atau sunnah Nabi saw. mencakup seluruh aktivitas kehidupan beliau.

Memang studi hadis termasuk salah satu bidang kajian keislaman yang sangat penting dan sekaligus menantang. Sisi pentingnya terletak pada kedudukan hadis sebagai salah satu sumber otoritatif ajaran Islam selain alQur'an. ${ }^{3}$ Sementara di sisi lain, pengembangan pemikiran terhadap hadis nabi ternyata jauh lebih kompleks dan berat ketimbang al-Qur'an. Pemahaman (baca: tafsir) terhadap al-Qur'an dapat begitu terbuka luas tanpa harus merasa khawatir terhadap berkurangnya otoritas al-Qur'an sebagai pedoman hidup umat Islam. Lain halnya dengan hadis, kebanyakan ulama lebih cenderung untuk mengendalikan diri dan mengutamakan sikap reserve (segan) dalam melakukan kajian ulang dan pengembangan pemahaman atau pemikiran terhadap hadis. Padahal perubahan kehidupan masyarakat global menghendaki perlunya pengkajian ulang terhadap hadis. ${ }^{4}$

Dalam hal ini, sikap keengganan ulama dalam pengkajian ulang hadis antara lain disebabkan karena subjek studi yang sangat kompleks dan rumit. Kompleksitas dan kerumitan itu bukan hanya terkait dengan sejarah hadis yang masih banyak diselimuti misteri dan kontroversi, tetapi juga menyangkut bidang kajian atau cabang-cabang ilmu hadis ('ulum al-hadits) yang sangat banyak. Menurut para ulama, jumlah disiplin ilmu-ilmu hadis itu bisa puluhan, ratusan, atau bahkan tidak terhingga. ${ }^{5}$ Boleh jadi karena kompleksitas dan kerumitan tadi, membuat studi hadis kurang banyak diminati sehingga ulama yang benar-benar ahli di bidang hadis pun sangat minim. ${ }^{6}$

Sejauh ini, studi hadis di berbagai pusat studi Islam -termasuk IAIN-, masih belum banyak beranjak dari kecenderungan klasik. Perkembangan modern (pembaruan) dalam bidang ilmu hadis juga masih jarang dikaji. Dengan

${ }^{3}$ Otoritas hadis sebagai sumber ajaran Islam didasarkan pada : (1) al-Qur'an; (2) Hadis

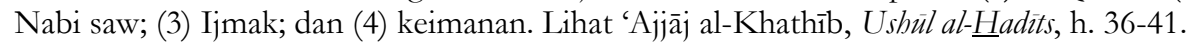

${ }^{4}$ Lihat pengantar Nizar Ali, Memahami Hadis Nabi; Metode dan Pendekatan, (Yogyakarta: CESaD YPI al-Rahmah, 2001), h. xi.

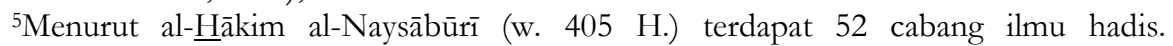
Sedangkan menurut perhitungan Ibn al-Shalāh (w. 643 H.), ada sekitar 65 cabang ilmu hadis. Di sisi lain, al-Hāāzimī (w. 584 H.) menyebutkan bahwa disiplin ilmu hadis mencapai 100 cabang. Sementara al-Suyūthī (w. 911 H.) menyatakan bahwa cabang ilmu hadis tidak lagi terhitung jumlahnya. Lihat misalnya Jalāl al-Dīn 'Abd al-Raḥmān ibn Abū Bakr al-Suyūthī,

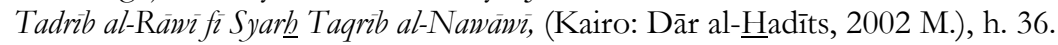

${ }^{6}$ Saifuddin, Pengembangan Studi Hadis Melalui Pendekatan Interdisipliner, makalah Workshop Keagamaan Ilmu-Ilmu Keushuluddinan tanggal 22 s.d. 25 Agustus 2005 (Banjarmasin: Fakultas Ushuluddin IAIN Antasari Banjarmasin, 2005), h. 1. 
mengutip ungkapan Nashr Hāmid Abū Zayd, bahwa wacana agama kontemporer terhadap 'ulüm al-Qur'àn dan 'ulüm al-badits, hanya sebatas mengulang dan mengulang. Hal itu terjadi karena banyak ulama yang mempunyai asumsi bahwa kedua jenis ilmu ini masuk dalam wilayah ilmu yang sudah matang dan sudah selesai (nadhijat wa ihbtaraqat), sehingga generasi belakangan tidak lagi memiliki apa pun yang dapat disumbangkan pada apa yang sudah dihasilkan oleh generasi sebelumnya. ${ }^{7}$ Padahal sebenarnya, masih terbuka peluang untuk mengembangkan studi hadis lebih lanjut. Dengan demikian, pendekatan dalam studi hadis dapat diupayakan agar rüh kandungan hadis dapat teraktualisasikan dalam kehidupan sekarang, atau dengan kata lain, hadis nabi akan terkesan dapat berinteraksi dalam segala waktu dan zaman.

Berbagai disiplin ilmu pengetahuan sangat diperlukan karena berperan penting dalam memperoleh pemahaman hadis secara komprehensif. Hal tersebut tidak saja dalam hubungannya dengan upaya pemahaman petunjuk ajaran Islam menurut teks dan konteksnya, tetapi juga harus digunakan dalam rangka dakwah dan tahap-tahap penerapan ajaran Islam. Oleh karena pengetahuan selalu berkembang, maka kegiatan dakwah dan penerapan ajaran Islam yang kontekstual menuntut penggunaan pendekatan yang sesuai dengan perkembangan pengetahuan dan keadaan masyarakat. Ini berarti bahwa dalam studi hadis diperlukan berbagai teori dari berbagai disiplin ilmu. ${ }^{8}$ Dalam konteks integrasi ilmu inilah, tulisan ini secara spesifik akan membahas diskursus 'Ulüm al-Hadits dalam wacana studi Islam.

\section{Pembahasan}

\section{Studi Hadis dalam Lintasan Sejarah}

Studi hadis, -seperti halnya bidang keilmuan Islam lainnya- semula muncul dalam tahap pengenalan, kemudian mengalami perkembangan hingga mencapai bentuk yang sempurna. Dalam hal ini, secara kronologis, Thahir alJawābī memotret tahap-tahap penting dalam perkembangan studi hadis, mulai tahap persiapan (al-tambidiyyah), peletakan dasar-dasarnya (al-ta'sisiyyah), penyusunan kaidah-kaidah (al-taqiidiyyah), hingga tahap penerapan (al-

${ }^{7}$ Nashr Hāmid Abū Zayd, Mafhūm al-Nash; Dirāsah fì 'Ulūm al-Qur'ān, diterjemahkan oleh Khairon Nahdliyyin dengan judul Tekstualitas al-Qur'an; Kritik terhadap Ulumul Qur'an, (Yogyakarta: LKiS, 2000), h. 3-4.

${ }^{8}$ Nizar Ali, Memahami Hadis Nabi, h. xi. 
tathbiqiyyab). ${ }^{9}$ Secara historis, 'Ajjāj al-Khathīb juga telah memetakan periodesasi perkembangan (al-tasalsul al-tärikhi) studi hadis, yang dimulai sejak abad kedua [fase al-Syafi'ī (w. 204 H.)] sampai abad ketujuh hijriyah [fase Ibn Shalāh (w. $643 \mathrm{H}).]{ }^{10}$ yang ditandai dengan kemunculan karya-karya mereka dalam kajian ilmu hadis.

Pertama, pada abad pertengahan kedua hijrah, muncul karya al-Syāfi'̄ dengan al-Risālah-nya, sebagai karya pertama dalam kajian usul fikih. Menurut al-Khathīb, dalam karyanya itu al-Syāfi'ī tidak hanya meletakkan dasar-dasar kaidah ilmu usul fikih, namun juga kaidah ilmu hadis (ushül al-badìts). Hal ini dapat dibuktikan dari bahasannya tentang kehujjahan hadis-hadis ähääd, syarat kesahihan hadis, keadilan para perawi, penolakan terhadap hadis-hadis mursal dan munqathi', periwayatan secara lafziah dan maknawiah, dan lain sebagainya. ${ }^{11}$ Kedua, seperempat abad kemudian, yaitu pada awal abad ketiga hijrah, muncul dua karya 'Alī ibn 'Abd Allāh al-Madīnī (w. 234 H.) dengan Ushül alSunnab dan Madrāabib al-Mubadditsin [dua volume], namun sayangnya kedua kitab tersebut menurut al-Khathīb tidak ada lagi sampai sekarang. Kemudian seperempat abad pasca wafatnya Ibn al-Madīnī, muncul karya Muslim ibn alHajjāj al-Naysābūrī (w. 261 H.) dengan al-Jämi' al-Shabüzh-nya yang memuat bahasan ushül al-badits dalam mukaddimah kitab tersebut yang sekalipun hanya merupakan pengantar kitab al-Jämi'-nya itu, namun dianggap sebagai madkhal yang representatif dalam studi hadis. ${ }^{12}$ Kemudian pada akhir abad ketiga hijrah, muncul Abū Bakr Aḥmad ibn Hārūn ibn Rawj al-Bardìjī (w. 301 H.) dengan sejumlah karyanya dalam ilmu hadis, seperti Ma'rifah al-Muttashil min al-Hadits wa al-Mursal wa al-Maqthü' wa Bayān al-Thuruq al-Shahizhah dan Ma'rifah Ushül al$\underline{H}$ adits, namun sayangnya kedua kitab tersebut menurut al-Khathīb juga tidak sampai ke tangan umat Islam sekarang.

${ }^{9}$ Uraian lebih detil tentang peta perkembangan studi hadis ini, lihat Muhammad

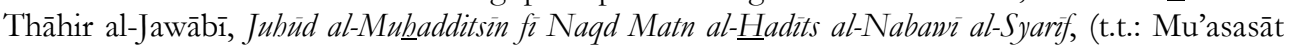
'Abd al-Karīm ibn 'Abd Allāh, t.th.), h. 94-132.

${ }^{10 ‘ A j j a ̄ j ~ a l-K h a t h i ̄ b, ~ U s h u ̈ l ~ a l-\underline{H} a d i t s, ~ h . ~ 451-456 . ~}$

${ }^{11}$ Muhammad ibn Idrīs al-Syāfi'̄', al-Risālah, (Beirut: Dār al-Kutub al-'Ilmiyyah, t.th.), misalnya pada bäb khabr al-wähild, h. 369-372.

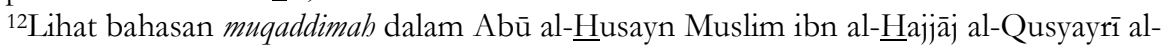
Naysābūrī, al-Jāmi’ al-Shahīh, (Beirut: Dār al-Fikr, t.th.), vol.1, h. 6-23. Dalam muqaddimah tersebut, Imam Muslim ada menjelaskan thabaqah (penggenerasian) para perawi yang diterima maupun yang tidak diterima hadisnya, tambahan dari perawi tsiqah, penolakan riwayat dari perawi yang lemah dan berdusta, signifikansi isnäd, dan lain sebagainya, yang kemudian ditutupnya dengan sahnya berhujjah dengan hadis mu'an'an. 
Ketiga, pada abad keempat hijrah, muncul karya-karya besar yang melingkupi seluruh bahasan ilmu hadis dan karya yang paling tertua pada abad

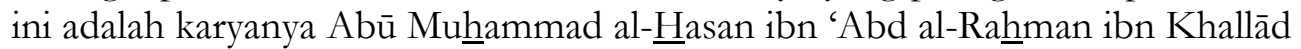
al-Rāmahurmūzī (w. 360 H.), yaitu al-Muhaddits al-Fäshil bayn al-Rāwñ wa al-Wä' yang dianggap sebagai kitab pertama yang melingkupi bahasan ilmu hadis. ${ }^{13}$ Setelah beberapa tahun pasca al-Rāmahurmūzī, muncul karya Abū al-Fadhl

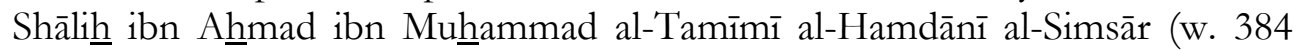
H.) dengan Sunan al-Tabdits-nya, namun kitab ini juga tidak ada lagi sampai sekarang. Kemudian pada akhir abad keempat dan awal abad kelima hijrah, muncul karya Abū 'Abd Allāh Muhammad ibn 'Abd Allāh ibn Hamdawiyyah

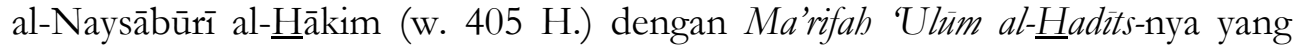
dalam kitab tersebut disebutkan sekitar lima puluh dua cabang ilmu hadis, meskipun belum disusun secara sistematis. ${ }^{14}$ Kitab ini dianggap sebagai karya tertua pada akhir abad keempat.

Keempat, sekitar setengah abad berikutnya, pada abad kelima, di wilayah barat Islam, muncul Abū 'Umar Yūsuf ibn 'Abd Allāh ibn Muhammad ibn 'Abd al-Barr al-Namirī al-Qurthubī (w. 463 H.) yang banyak menyusun karya di bidang hadis dan ilmu hadis, diantaranya yang terkait dengan tema bahasan ilmu hadis adalah mukaddimah kitabnya yang berjudul al-Tambid limá fi alMuwaththa' min al-Ma'añ wa al-Asānìd. Pengantar kitabnya tersebut dianggap alKhatīb menghimpun banyak bahasan kaidah usul hadis. Sementara di wilayah timur Islam muncul Abū Bakr Aḥmad ibn 'Alī ibn Tsabit al-Bughdādī, atau yang dikenal dengan sebutan al-Khathīb al-Bughdādī (w. 473 H.) dengan karyanya al-Kifäyah fi $\mathrm{T} l m$ al-Riwayah yang dianggap sebagai kitab ilmu hadis yang terlengkap saat itu karena memuat aturan-aturan periwayatan (qawānin alriwayyah). ${ }^{15}$ Selain itu, karyanya yang lain seperti al-Jämi' li Akbläq al-Rāwñ wa

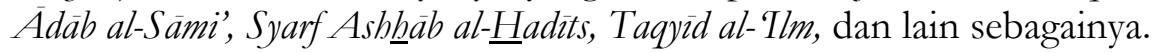

Kelima, pada abad keenam, pasca al-Khatīb al-Bughdādī, di wilayah barat Islam, muncul Abū al-Fadhl 'Iyādh ibn Mūsā ibn 'Iyād al-Yahsūbī al-

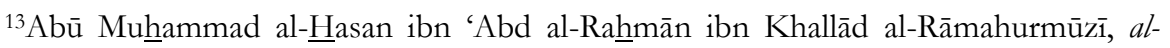
Mubaddits al-Fāshil bayn al-Rāwñ wa al-Wä̀̄, (Beirut: Dār al-Fikr, 1984), misalnya tentang isnād, hlm. 20.

${ }^{14} \mathrm{Abū}$ 'Abd Allāh Muhammad ibn 'Abd Allāh al-Naysābūrī al-H̄ākim, Ma'rifah 'Ulūm

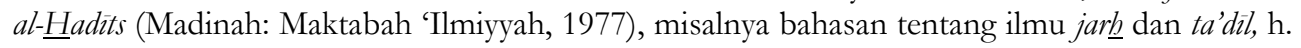
52-58.

${ }^{15} \mathrm{Abū}$ Bakr Aḥmad ibn 'Alī ibn Tsābit [al-Khathīb al-Bughdādī], al-Kifāyah fì $\mathrm{Tlm}$ alRiwaayah, (Beirut: Dār al-Kutub al-'Ilmiyyah, 1988), lihat misalnya tentang keadilan sahabat, h. 46-52. 
Sababī (w. 544 H.) dengan karyanya al-Ilmä' ilā Ma'rifah Ushūl al-Riwaàyah wa Taquìd al-Simā'. Di abad ini juga muncul Abū Hafsh 'Umar ibn 'Abd al-Majīd al-Yānashī (w. 580 H.) dengan karyanya Mā Lā Yasma' al-Mubaddits Jublah.

Keenam, pada abad ketujuh, banyak bermunculan karya-karya ilmu hadis dan yang paling masyhur pada abad ini adalah karyanya Taqy al-Dīn Abū 'Umar wa 'Utsmān ibn 'Abd al-Raḩmān al-Syahrazūrī atau yang dikenal dengan sebutan Ibn al-Shalāh (w. 643 H.) yang berjudul Ulüm al- $\underline{\text { Hadits }}$ atau Muqaddimah Ibn al-Shaläb. Dalam kitab ini disebutkan sekitar lima puluh lima cabang ilmu hadis, lebih banyak dari kitab almenghimpun pendapat-pendapat ulama klasik (al-mutaqaddimūn). ${ }^{16}$

Dari periodesasi perkembangan ilmu hadis klasik al-Khatîb tadi, dapat diketahui bahwa karya al-Risālah al-Syāfi'̄ lah yang dianggap paling awal dalam studi hadis meskipun belum terpisah dari studi lain yang disusunnya [usul fikih]. Namun yang jelas, perodesasi perkembangan studi hadis, yang diajukan al-Jawābī ataupun al-Khathīb tadi, baik dari sisi historis maupun metodologis, nampaknya telah cukup baik memotret momen-momen penting yang terjadi selama proses perkembangan studi hadis.

\section{Kerangka Metodologi Studi Hadis; Tinjauan Teoritis}

Dalam studi hadis, setidaknya terdapat dua bentuk kajian yang perlu diketahui pengkaji hadis, yaitu naqd al-badits [kritik hadis] dan fiqh al-badits [pemahaman hadis]. Studi yang pertama lebih menekankan pada aspek otoritas dan validitas (kesahihan) hadis dilihat dari sisi kritik hadis, baik sanad maupun matn-nya. ${ }^{17}$ Adapun studi yang kedua lebih menekankan upaya metodologis terhadap pemahaman kontekstual hadis. ${ }^{18}$

Adapun dalam kajian kritik hadis, dikenal ada dua pola, yaitu kritik intern (al-naqd al-däkhili) dan kritik ekstern (al-naqd al-khärijī). Kritik ekstern adalah kritik untuk mendapatkan keotentikan suatu sumber melalui aspek di

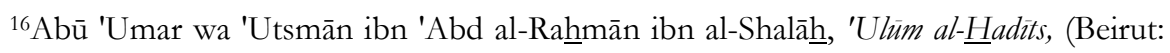
Dār al-Fikr, 1986), misalnya bahasan tentang hadis sahih, h. 41.

${ }^{17}$ Referensi yang dapat diakses untuk kajian ini dapat dilihat misalnya dalam Muhammad Mushthafā al-A'zhamī, Manhaj an-Naqd 'ind al-Mubadditsin, (Riyādh: Syirkah ath-

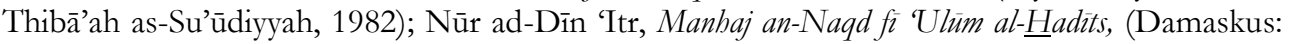
Dār al-Fikr, 1997); Muhammad Thāhir al-Jawābī, Jubūd al-Mubadditsin fì Naqd Matn al-Hadìts alNabawr̂ al-Syarif, (Tunisia: Mu'assasah 'Abd al-Karīm ibn 'Abd Allāh, t.th.); dan M. Syuhudi Ismail, Metodologi Penelitian Hadis Nabi, (Jakarta: Bulan Bintang, 1992).

${ }^{18}$ Nizar Ali, Memahami Hadis Nabi, h. xii. 
luar teks, yang dalam ilmu hadis disebut kritik sanad. ${ }^{19}$ Sementara kritik intern merupakan kritik terhadap isi sumber atau teks sumber yang disebut kritik matn. ${ }^{20}$ Dalam kajian sejarah, kritik sumber dokumen juga dilakukan dalam dua aspek; pertama, eksternal, diarahkan untuk menentukan keotentikan dokumen; 1) apakah secara material fisik dokumen tersebut asli atau palsu; dan 2) siapa yang menjadi sumber; kedua, internal, diarahkan untuk meneliti keabsahan isi dokumen, dipercaya atau tidak, dapat diterima secara historis atau tidak, tujuan penulisan dan lain sebagainya. Namun dalam kajian hadis, secara aplikatif, kritik eksternal terhadap dokumen kitab hadis, tidak ditujukan untuk melihat keaslian fisik dokumen kitab hadis, tetapi kepada sumber kitab hadis. Oleh karena dalam kitab hadis tidak hanya melibatkan satu sumber saja -penyusun kitab hadis (mukharrij)-, maka kajian terhadap sumber dokumen harus diarahkan kepada semua orang yang terlibat dalam transmisi hadis [para perawi dalam sanad hadis tersebut, mulai mukharrij sampai sahabat yang menerima hadis dari Nabi saw.].

Dalam kajian kritik hadis ini, kemungkinan hasil penelitiannya dapat dilihat dari dua sisi; yaitu kuantitas [jumlah] perawi hadis dan kualitas [keandalan] sanad dan matn-nya. ${ }^{21}$ Dilihat dari sisi yang pertama, hadis yang diteliti, jika memiliki jalur-jalur transmisi yang banyak tidak terhingga, maka disebut mutawätir, yaitu yang diriwayatkan oleh orang banyak, yang menurut ukuran rasio dan kebiasaan, mustahil para perawi yang jumlahnya banyak itu bersepakat untuk berdusta. ${ }^{22}$ Kemudian jika hadis tersebut hanya memiliki jalur-jalur transmisi yang terbatas jumlahnya, maka disebut ăbăad, yaitu yang

${ }^{19}$ Sanad merupakan merupakan rangkaian para perawi yang meriwayatkan hadis. Dalam hal ini, Syuhudi Ismail melalui disertasinya telah membuktikan bahwa kaedah kesahihan sanad yang dipakai para ulama dalam meneliti keabsahan hadis ternyata memiliki tingkat akurasi yang tinggi. Selanjutnya lihat M. Syuhudi Ismail, Kaedah Kesabihan Sanad; Telaah Kritis dan Tinjauan dengan Pendekatan Ilmu Sejarah, (Jakarta: Bulan Bintang, 1995).

${ }^{20}$ Matn merupakan redaksi atau materi dari hadis itu sendiri. Mengenai kaedah

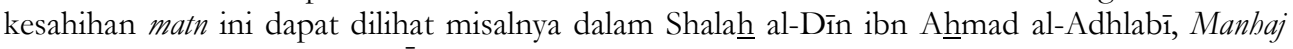
Naqd al-Matn, (Beirut: Dār al-Āfāq al-Jadīdah, 1983).

${ }^{21}$ M. Syuhudi Ismail, Metodologi Penelitian Hadis Nabi, h. 31-32.

${ }^{22}$ Lihat misalnya Maḥmūd al-Thahhān, Taysìr Mushthala $\underline{\text { al }}$ al $\underline{H} a d i \bar{t}$, (Beirut: Dār al-

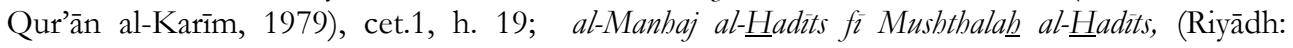
Maktabah al-Ma'ārif, 2004), cet.1, h. 10-11. 
diriwayatkan oleh sejumlah orang [perawi] yang tidak mencapai tingkatan mutawātir. ${ }^{23}$

Jika hadis tersebut ternyata berstatus mutawātir, maka berakhirlah kegiatan kritik hadis. Artinya, kajian sanad dan matn-nya tidak perlu lagi dilakukan, karena status ke-mutawätir-an hadis itu telah memberikan keyakinan yang pasti, bahwa ia memang bersumber dari Nabi Muhammad saw. dan kedudukannya sama dengan periwayatan al-Qur'an. Sebaliknya, jika hadis tersebut berstatus $\bar{a} \underline{h} \bar{a} d$, maka kegiatan penelitian akan berlanjut pada sisi yang kedua, yaitu kajian terhadap keandalan sanad dan matn-nya. Keadaan sanad dan matn hadis itu sendiri cukup bervariasi, mengingat kualitas kepribadian dan kapasitas keilmuan perawi juga beragam.

Untuk mempermudah identifikasi, maka ulama memformulasikan berbagai istilah untuk kualitas hadis yang standarisasinya sampai saat ini mengacu pada tiga macam; shahizh, hasan, dan dha'if. ${ }^{24}$ Dalam hubungannya dengan kajian sanad dan matn ini, harus dimaklumi bahwa kualitas hadis yang diperoleh akan bervariasi. Misalnya hadis yang diteliti sanad-nya sahih, tetapi matn-nya dha'if, atau sanad-nya dha'if, tetapi matn-nya sahih, atau sanad dan matnnya sama-sama sahih, atau sanad dan matn-nya sama-sama dha'if. Variasi ini akan bertambah lagi dengan adanya kategori hasan. Oleh karena itu, hadis yang sanadnya sahih dan matn lemah, atau sebaliknya, sanad-nya lemah dan matn-nya sahih, tidak dapat dinyatakan sebagai hadis sahih.

Syuhudi Ismail (w. 1998 M.), dalam risetnya telah membuktikan secara ilmiah, bahwa kaidah kesahihan sanad hadis yang diformulasi oleh ulama-ulama hadis klasik ternyata memang memiliki tingkat akurasi tinggi. Dari tesis ini, maka suatu hadis yang sanad-nya sahih, seharusnya matn-nya juga sahih. Namun pada kenyataannya ada saja hadis yang sanad-nya sahih, tetapi matn-nya lemah. Hal ini bukanlah disebabkan oleh kaidah kesahihan sanad yang kurang akurat, tetapi karena ada kemungkinan faktor-faktor lain, di antaranya seperti;

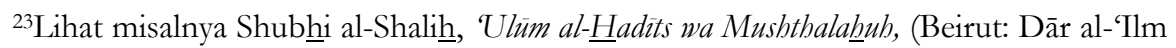

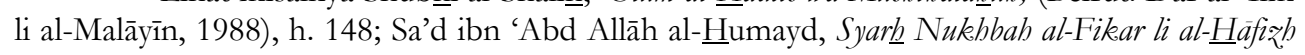
Ibn Hajr al-'Asqalāni, (t.tp.: Dār 'Ulūm al-Sunnah, t.th.), h. 15.

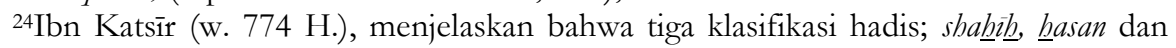
dha'if, berlaku mulai zaman al-Turmudzī, dan pada zaman sebelumnya, pembagian tersebut hanya dua saja; sahih dan dha'if. Dalam hal ini, al-Turmudzī mulai mempopulerkan istilah hasan secara formal di kalangan ulama hadis. Selanjutnya lihat Abū al-Fidā' Ismā'îl ibn 'Umar ibn

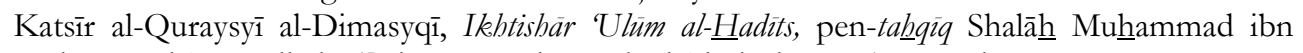
Muhammad 'Uwaydhah, (Beirut: Dār al-Kutub al-'Ilmiyah, 1989), cet.1, h. 30. 
Pertama, karena kaidah kesahihan sanad tidak diterapkan secara konsekuen, seperti terjadi kesalahan penilaian terhadap suatu riwayat, yang mungkin disebabkan ketentuan penilaian keandalan perawi (al-jar $\underline{b}$ wa al-ta'dil) tidak dilaksanakan sebagaimana mestinya, atau mungkin terjadi kekeliruan pribadi perawi yang dinilainya; atau terjadi kekeliruan penafsiran kata-kata atau singkatannya, yang menghubungkan perawi dengan perawi terdekat sebelumnya yang terdapat dalam sanad; kedua, karena terjadi perbedaan pendapat tentang unsur-unsur kaidah kesahihan sanad hadis itu sendiri; ketiga, karena terjadi perbedaan sikap ulama hadis dalam menilai kualitas perawi hadis tertentu, sebab di antara mereka ada yang bersikap ketat (mutasyaddid), longgar (mutasähil) dan pertengahan (mutawassith); keempat, karena telah terjadi periwayatan hadis secara makna; kelima, karena matn hadis yang bersangkutan berkaitan dengan masalah näsikh-mansükh, atau äm-khäsh, atau mujmal-mufashshal; dan keenam, karena kaidah kesahihan matn hadis yang digunakan masih belum akurat. $^{25}$

Dengan argumentasi ini, Syuhudi nampaknya juga sepakat bahwa kesahihan sanad hadis sangat menentukan kesahihan matn-nya. Pendapat yang senada juga dikemukakan oleh Nūr al-Dīn 'Itr, bahwa kelemahan pada matn hadis tidak akan terjadi jika sanad-nya sudah sahih, ${ }^{26}$ sebab dalam kaidah kesahihan sanad itu, para perawinya dituntut untuk tsiqah, dalam arti memiliki sifat 'ádälah dan $d h a \bar{b} t h .{ }^{27}$ Dengan dua sifat ini, seorang perawi seharusnya

\footnotetext{
${ }^{25}$ Lihat uraian M. Syuhudi Ismail, Kaedah Kesabihan Sanad Hadis, h. 228-229; Metodologi Penelitian Hadis Nabi, h. 123-124.

${ }^{26}$ Lihat Nūr al-Dīn 'Itr, Lamạ̄āt Müjazah fì Manāhij al-Mubadditsin al-'Āmmah fì alRiwāyah wa al-Tashniff, (Damaskus: Dār al-Farfūr, 1999), h. 21-22.

${ }^{27}$ Dalam terminologi ilmu hadis, 'adälah merupakan 'tabiat atau sifat dasar yang ada dalam diri seseorang, yang mendorong pemiliknya untuk senantiasa berada dalam orbit ketakwaan dan kehormatan (murüah)'. Sejumlah ulama hadis, seperti al-Hākim (w. 405 H.), Ibn al-Shalāh (w. 643 H.) dan al-Nawāwī (w. 676 H.), telah memberikan kriteria yang lebih rinci atau kaidah minor bagi perawi yang 'ádil tersebut. Lebih lanjut lihat misalnya uraian al-Khathìb, Ushül al-Hadits, h. 231; 'Itr, Manhaj al-Hadits, h. 79. Sedangkan dhabth dalam terminologi ilmu hadis, diartikan dengan 'kondisi terjaga dan tidak pelupa, sejak menerima hadis (al-tabammul) hingga ketika menyampaikannya (al-adä) kepada orang lain'. Dalam terma yang lebih rinci, perawi yang dhäbith adalah yang 'mampu dengan mendengar pembicaraan sebagaimana mestinya, memahami arti pembicaraan secara benar, kemudian menghafalnya dengan sungguhsungguh dan sempurna tanpa keraguan, sehingga mampu menyampaikannya kepada orang lain dengan baik kapan saja dia menginginkannya'. Selanjutnya lihat misalnya uraian 'Abd al-

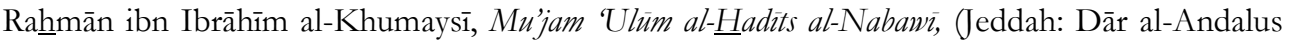
al-Khadhrā', 1419 H.), cet.1, h. 136; Muhammad Dhiyā' al-Rahnmān al-A'zhamī, Mu'jam
} 
bersikap selektif terhadap hadis-hadis yang diterimanya, yang kemudian diriwayatkannya kepada orang lain. Di samping ketiga kualitas tersebut, masih ada lagi satu kemungkinan hasil kajian hadis, yaitu bahwa hadis yang diteliti ternyata tidak memenuhi syarat untuk dinyatakan sebagai hadis. Tegasnya, hadis yang diteliti itu adalah palsu (mawdh $\bar{u}^{\prime}$. Dengan demikian, studi hadis dalam bentuk kritik hadis ini tidak terlepas dari empat kemungkinan; shabiziz, basan, dha'îf, atau bahkan mawdhü'.

Dalam kerangka penelitian atau kritik hadis, ada setidaknya beberapa tahapan operasional yang perlu dilakukan. Syuhudi Ismail, dalam risetnya telah mensintesakan kerangka metodologis kritik hadis yang diformulasikan para ulama dan kritikus hadis dalam sejumlah tahapan; 1) melakukan takhrij terhadap hadis yang akan diteliti dalam rangka konfirmasi letak riwayat tersebut dalam sumber-sumber aslinya; 2) melakukan i'tibār terhadap sanad-sanad hadis yang telah terakumulasi dari kegiatan takhrij; 3) melakukan kritik sanad dan matn, dengan menerapkan kaidah-kaidah kesahihan sanad dan matn hadis; 4) mengambil simpulan (natijah) terhadap kegiatan penelitian sanad dan matn tersebut. $^{28}$

Untuk istilah takhrīj sendiri, menurut al-Khayr Ābādī dan al-Thahhān, tidak ditemukan arti yang definitif dalam karya para ulama hadis klasik, ${ }^{29}$ meskipun terma tersebut belakangan digunakan para peneliti hadis untuk 'menunjukkan atau mengemukakan letak asal hadis dari sumber-sumbernya yang asli, yakni berbagai kitab yang di dalamnya dikemukakan hadis tersebut secara lengkap dengan sanad-nya masing-masing; lalu untuk kegiatan penelitian, dijelaskan kualitas hadis yang bersangkutan. ${ }^{30}$

Dari terma takbrij tadi, ada beberapa point yang umumnya digunakan dalam studi hadis; 1) menunjukkan letak hadis dalam sumber-sumber yang asli; 2) menerangkan rangkaian sanad; dan 3) menjelaskan nilai atau kualitas hadis tersebut jika diperlukan. Definisi inilah yang juga menjadi acuan Dhiyā' alRaḩmān al-A'zhamī ketika menjelaskan terma takhrīj. Bahkan menurut al-

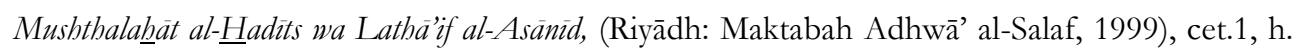

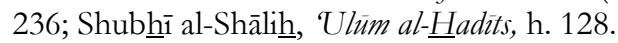

${ }^{28}$ Lihat uraian M. Syuhudi Ismail, Metodologi Penelitian Hadis Nabi, h.41-158; Kaedah Kesabihan Sanad Hadis, h. 208-222.

${ }^{29}$ Uraian lebih lanjut mengenai istilah-istilah takhrï yang digunakan ulama hadis klasik,

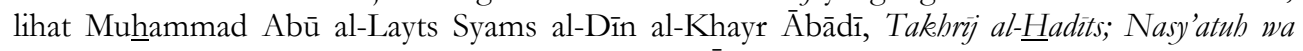
Manhajizyyatuh, (Malaysia: al-Jāmi'ah al-Islāmiyyah al-Ālamiyyah, 1997), h. 7-8.

${ }^{30}$ Lihat Mậmud al-Thahhāan, Ushūl al-Takhrìj wa Dirāsah al-Asānìd, (Riyādh: Maktabah al-Ma'ārif, 1996), h. 10. 
Khayr Ābādī, takhrij dalam terma ini, merupakan gambaran tahqiq sempurna terhadap hadis, dan menjadi kajian hadis yang komprehensif dari segala aspeknya, atau dengan ungkapan lain, yaitu 'operasionalisasi holistik studi hadis'

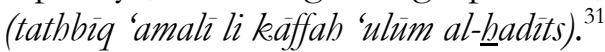

Dalam konteks inilah, timbul kesan bahwa istilah takhrïj, dalam persepsi sebagian pengkaji hadis, sama halnya dengan kegiatan penelitian atau kritik hadis. Hal ini dikarenakan seorang peneliti, dituntut untuk mengkonfirmasi hadis dari sumber-sumber aslinya, mengeksplorasi varian lafal hadis beserta sanad-nya, menelisik pernyataan para ulama [kritikus] hadis terhadap para perawinya, mengkaji sanad dan matn-nya, sampai pada satu kesimpulan yang jelas terhadap [kualitas] hadis yang di-takbrij. ${ }^{32}$ Persepsi ini berbeda dengan Syuhudi Ismail, yang menganggap takhrij, sebagai langkah awal dalam melakukan penelitian hadis, karena hanya bersifat konfirmatif semata terhadap sumber-sumber hadis, ${ }^{33}$ untuk kemudian dibuat sketsa grafis seluruh jalur periwayatan, atau yang disebut ddengan i'tibär al-sanad .

Untuk praktek takhrij hadis sendiri, ada sejumlah metode yang dikemukakan oleh para ahli hadis. Dalam hal ini, Syuhudi Ismail memetakannya dalam dua bentuk; a) takhrï al-badits bi al-alfäăh (penelusuran hadis berdasarkan lafal matn-nya); b) takhrïj al-hadits bi al-mawdhü' (penelusuran hadis berdasarkan tema masalah yang dibahas dalam matn hadis tersebut). ${ }^{34}$ Kedua metode ini dapat merujuk kepada indeks hadis susunan orientalis A.J. Wensinck (w. 1939 M.), yang telah diterjemahkan dalam versi Arab oleh Muhammad 'Abd al-Bāqī, yaitu al-Mu'jam al-Mufahras li Alfärh al-Hadìts alNabawi, untuk metode pertama [berdasarkan lafal] dan Miftäh Kunīz, al-Sunnah untuk metode kedua [berdasarkan tema]. ${ }^{35}$

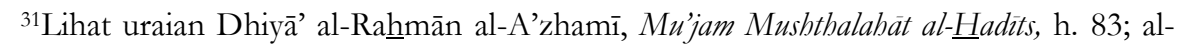
Khayr Ābādī, Takbrīj al- $\underline{H}$ adits, h. 8.

32al-Khayr Ābādī, Takbrìj al- $\underline{H}$ adìts, h. 8.

${ }^{33}$ M. Syuhudi Ismail, Metodologi Penelitian Hadis Nabi, h. 44.

${ }^{34}$ M. Syuhudi Ismail, Cara Praktis Mencari Hadis, (Jakarta: Bulan Bintang, 1991), h. 17.

${ }^{35}$ Menurut Syuhudi, bagi para peneliti hadis pemula, metode pertama lebih mudah dan praktis, karena dengan hanya mengetahui salah satu kata dalam matn hadis, sudah dapat ditelusuri dalam sumber-sumber aslinya. Meskipun demikian, cakupan al-Mu'jam al-Mufahras li

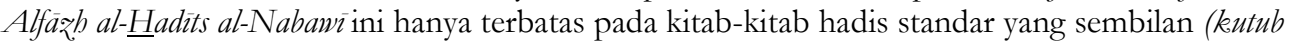

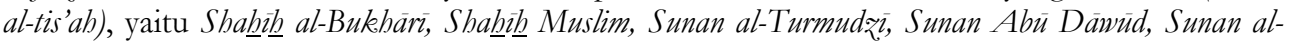
Nasä'i, Sunan Ibn Mäjah, Sunan al-Därimì, Muwaththa' Mälike dan Musnad A Almad ibn Hanbal, sehingga ketika hadis-hadis yang di-takhrij misalnya, tidak termasuk dalam kitab-kitab tersebut, maka harus menggunakan kamus hadis lainnya yang memuat hadis-hadis yang diteliti. Sedangkan Miftäh Kunīz al-Sunnah, selain memuat kitab hadis sembilan, juga ada tambahan 
Sedangkan dalam kajian pemahaman hadis, juga terdapat sejumlah petunjuk dan ketentuan umum agar dapat menghasilkan pembacaan yang tepat dan akurat terhadap substansi hadis. Dalam hal ini, Yūsuf al-Qardhawi menawarkan beberapa alternatif metodologis dalam studi fiqh al-hadits ini dalam karyanya Kayf Nata'ämal ma' al-Sunnah al-Nabawiyyah, dengan penjelasan berikut. ${ }^{36}$

Pertama, memahami hadis sesuai dengan petunjuk al-Qur'an (fahm alsunnah fi dhaw' al-Qur'an al-Karim), sebab hadis secara fungsional merupakan penjelasan dan tafsiran terhadap al-Qur'an, baik dalam tataran teoritis maupun praktisnya. Ini berarti bahwa kandungan al-Qur'an sebagai sesuatu yang dijelaskan dan kandungan hadis sebagai sesuatu yang menjelaskannya semestinya selaras dan tidak mungkin bertentangan antara keduanya. Sekalipun umpamanya ada pertentangan antara al-Qur'an dan hadis, kemungkinannya hanya dua; hadisnya yang tidak sahih, atau pemahaman terhadap hadis itu yang tidak sahih.

Kedua, menghimpun hadis-hadis yang terjalin dalam satu tema (jam' al-

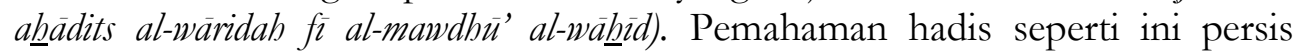
seperti tafsir mawdhü’ dalam kajian ilmu al-Qur'an. Penghimpunan hadis-hadis dalam satu tema ini penting agar dapat diketahui mutasyäbih dan mublkam-nya, muthlaq dan muqayyad-nya, 'äm dan khäsh-nya, sehingga maksud dan kandungan hadis tersebut menjadi jelas karena satu hadis dengan hadis lainnya bisa saling menjelaskan.

Ketiga, kompromisasi (al-jam') atau pemakaian dalil yang lebih kuat (al-

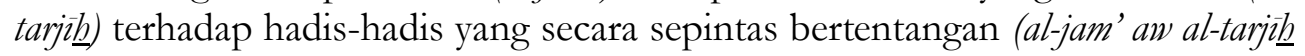
bayn mukhtalaf al-hadits). Dari dua cara ini, nampaknya al-Qardhāwī lebih cenderung kepada al-jam' sebagai metode yang diprioritaskan (al-jam' muqaddam 'alā al-tarjīh). Namun demikian, kompromisasi itu hanya berlaku pada hadishadis sahih yang tampak bertentangan. Sedangkan hadis-hadis yang tidak diketahui asal-usulnya, atau hadis tersebut lemaha apalagi palsu, maka tidak perlu dihiraukan, kecuali untuk menjelaskan kepalsuan dan kebatilannya.

Adapun tahap kedua yang ditawarkan oleh Yūsuf al-Qardhāwī naskh dan al-tarjizh. Di kalangan ahli hadis terjadi perbedaan pendapat tentang adanya naskh (penghapusan). Sebagian menyatakan tidak ada naskh, sedangkan yang

sejumlah kitab hadis lainnya, meskipun juga terbatas, yaitu Musnad Zayd ibn 'Ali, Musnad Abū

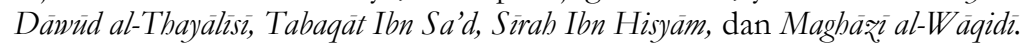

${ }^{36}$ Lihat lebih lanjut Yūsuf al-Qardhawī, Kayf Nata'āmal ma' al-Sunnah al-Nabawiyyah; Ma'ālim wa Dhawabith, (USA: al-Ma’had al-'Ālamī li al-Fikr al-Islāmī, 1992), h. 93-181. 
lain menyatakan ada naskh dalam hadis Nabi. Dalam hal ini, apabila ada dua hadis yang saling bertentangan tidak bisa digabungkan, sementara diketahui mana hadis yang diucapkan lebih dahulu dan mana yang kemudian, maka hadis yang datang lebih dahulu di-naskh (dihapus kandungannya) oleh hadis yang datang kemudian. Hadis yang datang belakangan (näsikh) yang diamalkan, sementara hadis yang datangnya lebih awal (mansükh) ditinggalkan.

Namun demikian, menurut al-Qardhāwī, kebanyakan hadis yang diasumsikan mansükh (dihapus), apabila diteliti lebih jauh, ternyata tidaklah demikian. Sebab di antara hadis-hadis tersebut ada yang dimaksudkan sebagai azimah (anjuran melakukan sesuatu walaupun berat), dan adapula yang dimaksudkan sebagai rukhsah (peluang untuk memilih yang lebih ringan pada suatu ketentuan). Karena itu, kedua-duanya mengandung kadar ketentuan yang berbeda, sesuai dengan kedudukannya masing-masing. Demikian juga adakalanya sebagian hadis bergantung pada situasi tertentu, sementara yang sebagiannya lagi bergantung pada situasi lainnya. Jelas bahwa adanya perbedaan situasi seperti itu, tidak berarti adanya penghapusan atau naskh.

Naskh, sebenarnya juga merupakan salah satu cara tarjīh, secara teoritis menjadi kajian ilmu hadis, bahkan banyak pakar hadis yang telah menyusun kitab-kitab tentang hadis-hadis yang näsikh maupun mansükh. Hanya saja menurut al-Qardhāwī, hadis-hadis yang diklaim ulama telah mansükh, bila diteliti lebih lanjut tidaklah selalu menunjukkan ke-mansükh-annya untuk kurun waktu yang tidak terhingga, tetapi lebih merupakan hadis yang sebenarnya berkait dengan peristiwa tertentu. Pendapat semacam ini telah disebut-sebut baik dalam kawasan ilmu hadis maupun Ilmu usul fikih.

Sedangkan tarjīh menurut al-Qardhāwi merupakan tahapan penyelesaian terhadap hadis-hadis yang tampaknya bertentangan, jika al-jam

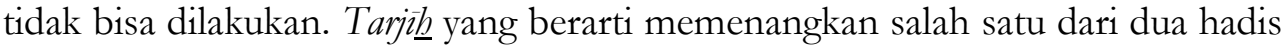
atau lebih yang tampak bertentangan, dengan berbagai alasan pen- tarjizh-an yang telah ditentukan oleh para ulama. Adapun cara-cara atau langkah-langkah tarjī, al-Qardhāwī tidak menyebutkannya secara rinci. Dia hanya menyatakan bahwa cara-cara itu dapat diketemukan dalam kitab Tadrib al-Ràn $i$ karya alSuyūthī (w. 911 H.), yang menyebutkan lebih dari 100 cara-cara tarjīh . Cara-cara yang demikian, sebenarnya juga dapat diketemukan dalam kaedah ilmu usul fikih maupun kaedah-kaedah dalam ilmu hadis. Sebagaimana dalam kasus naskh, al-Qardhāwī juga tidak mengemukakan satu contoh pun tentang cara tarjī terhadap hadis-hadis yang tampak bertentangan (mukhtalif). Hal demikian barangkali, menurutnya cara yang paling sah dalam menyelesaikan hadis-hadis 
yang tampak bertentangan hanyalah dengan cara al-jam' (penggabungan atau pengkompromian).

Keempat, memahami hadis dengan pertimbangan latar belakang kemunculan hadis, situasi dan kondisi ketika hadis diucapkan serta tujuan-

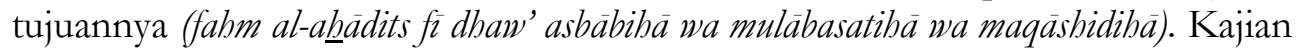
seperti ini dianggap penting untuk menghasilkan pemahaman yang komprehensif. Pendekatan seperti inilah yang disebut kontekstual dengan memperhatikan dan mengkaji keterkaitannya dengan peristiwa atau situasi yang melatarbelakangi ('illah) munculnya hadis-hadis tersebut, atau dengan kata lain, dengan memperhatikan dan mengkaji konteksnya.

Kelima, membedakan antara sarana yang berubah dan sasaran yang tetap (al-tamyiz bayn al-wasilah al-mutaghayyirah wa al-hadaf al-tsäbit li al-haditts). Dalam hal ini, analisis konteks-redaksional akan memberikan perspektif baru tentang semangat teks hadis secara keseluruhan yang pada gilirannya akan memberikan pemahaman tentang maksud atau tujuan (madlül / badaf) yang terkandung dalam sebuah hadis. Bahwa ketika disebutkan media (wasilah) sebagai wadah bagi terwujudnya tujuan adalah hal yang wajar. Dari sini, harus dilakukan pemahaman yang bersifat filosofis, yakni menarik tujuan atau maksud sebuah ucapan Rasulullah saw. Untuk itu maksud atau tujuan yang diinginkan dengan media haruslah dibedakan dengan jelas. Ini disebabkan karena tujuan atau maksud merupakan realitas yang bersifat statis dan universal. Tetapi media senantiasa berkembang dan terus berkembang. Maka yang harus dijadikan pegangan dalah tujuan dan maksud yang dikandung sebuah hadis, karena media merupakan pendukung bagi tercapainya sebuah maksud.

Keenam, memilah ungkapan-ungkapan hadis yang bersifat denotatif dan

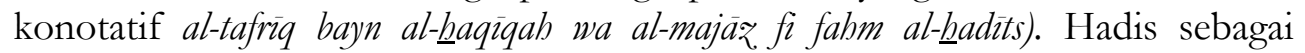
sebuah pesan-pesan keagamaan disampaikan dalam sebuah bahasa yang tentunya juga bersifat keagamaan. Salah satu ciri yang paling menonjol dalam bahasa keagamaan adalah seringnya pemakaian bahasa metaforis. Hal ini agaknya tidak dapat dihindari karena untuk membahasakan dan mengekspresikan tentang Tuhan dan objek yang abstrak, manusia tak bisa tidak mesti menggunakan ungkapan yang familiar dengan dunia indrawi, dengan bahasa kiasan dan simbol-simbol.

Bahasa metaforis atau majaz dalam bahasa Arab dapat diungkapkan sebagai kata yang dipakai bukan pada makna yang diperuntukkan baginya (bukan makna aslinya) karena adanya hubungan yang diikuti dengan tandatanda yang mencegah penggunaan makna asli tersebut. Jadi, pengalihan makna 
hakiki kepada majazi dilakukan karena adanya 'aläqah (korelasi) dan qaiñah (tanda-tanda) yang menghalangi pemakaian makna asli (hakiki) tersebut. Pemakaian bahasa metaforis dalam hadis tidak hanya terbatas hadis yang bersifat informatif, tetapi juga pada hadis-hadis yang mengandung muatan hukum (hadis-hadis hukum). Tiba di sini memahami suatu perkataan sebagai majaz, kadang kala menjadi suatu keharusan, sebab jika tidak demikian seseorang dapat keliru menyimpulkan sebuah tujuan yang dimaksudkan hadis.

Ketujuh, membedakan hadis-hadis yang berbicara tentang alam gaib dan alam nyata (al-tafriq bayn al-ghayb wa al-syahädah). Sebagaimana al-Qur'an, hadis pun juga banyak berbicara dalam persoalan-persoalan gaib seperti malaikat, jin, syaitan, 'arsh, kursi, qalam, dan lain sebagainya. Persoalan-persoalan tersebut tidak bisa diukur dengan logika karena memang di luar jangkauan akal pikiran dan indera manusia. Maka ketika hadis-hadis telah jelas kesahihannya, maka sudah sewajibnya umat Islam mempercayai dan mengimaninya. Namun ada saja mazhab teologi yang menolak keberadaan hadis-hadis tentang alam gaib tersebut, seperti Muktazilah yang menolak misalnya hadis-hadis tentang azab dan nikmat kubur. Padahal antara alam dunia dan alam akhirat tentunya masing-masing aturan dan ketentuan (qämīn) tersendiri yang tidak mungkin untuk diperbandingkan atau disamakan. Karena itulah menurut al-Qardhāwī, kesalahan mendasar dari sikap penolakan Muktazilah terhadap hadis-hadis tentang alam gaib ini adalah menyamakan keadaan alam gaib dengan alam zahir, atau mengqiyaskan alam akhirat dengan alam dunia.

Kedelapan, memastikan makna dan konotasi kata-kata dalam hadis (alta'kìd min madlülät alfäarh al-baditss). Hadis yang diucapkan Nabi relevan dengan ruang dan waktu, baik itu dari segi sosial budaya maupun alam lingkungan. Dari sini, pemahaman sebuah kata pun haruslah dalam waktu dan ruang di mana hadis itu diucapkan, meskipun kata itu dalam ruang dan waktu pembaca atau penafsir sering dipakai dengan makna yang lebih luas. Artinya sebuah kata tidak diberi muatan makna yang terlalu jauh melampaui masanya.

Dari sejumlah alternatif metodologis yang ditawarkan al-Qardhāwī, jelaslah bahwa dalam memahami hadis, tentunya tidak hanya menggunakan pendekatan tekstual, tetapi juga [dalam beberapa hal] mesti menggunakan pendekatan kontekstual. Hal ini dapat dimaklumi karena dalam kaitannya sebagai sumber pokok ajaran Islam, hadis pada umumnya lebih merupakan penafsiran kontekstual dan situasional atas ayat-ayat al-Qur'an dalam merespons pertanyaan para sahabat Nabi saw. Dengan demikian, hadis merupakan interpretasi Rasulullah saw. yang dimaksudkan untuk menjadi 
pedoman bagi para sahabat dalam mengamalkan ayat-ayat al-Qur'an. Karena kondisi sahabat dan latar belakang kehidupannya berbeda, maka petunjukpetunjuk yang diberikan nabi berbeda pula. Pada sisi lain, para sahabat pun memberikan interpretasi yang berbeda terhadap hadis nabi. Dari sini, maka hadis pada umumnya bersifat temporal dan kontekstual.

Situasi sosial budaya dan alam lingkungan semakin lama semakin terus berubah dan berkembang. Dengan semakin jauh terpisahnya hadis dari situasi sosial yang melahirkannya, maka sebagian hadis nabi terasa tidak komunikatif lagi dengan realitas kehidupan sosial saat ini. Karena itu pemahaman atas hadis nabi merupakan hal yang mendesak, tentu dengan acuan yang dapat dijadikan sebagai standarisasi dalam memahami hadis. Realitanya bahwa hadis nabi lebih banyak dipahami secara tekstual, bahkan belakangan gejala ini muncul di kalangan generasi muda Islam, tidak saja di Indonesia, tetapi juga di banyak negeri Islam lainnya. Pendekatan ini, -terhadap sebahagian hadis merupakan satu keharusan- tidak selamanya mampu memberikan jawaban terhadap persoalan-persoalan yang muncul belakangan, bahkan malah menjadi sesuatu yang kontradiktif sehingga memalingkan kepercayaan terhadap hadis nabi.

Dalam konteks ini kemudian Syuhudi Ismail berkesimpulan bahwa ada kemungkinan sebuah hadis tertentu lebih tepat dipahami secara tersurat (tekstual), sedang hadis lainnya lebih tepat dipahami secara tersirat (kontekstual). Pemahaman dan penerapan hadis secara tekstual dilakukan bila yang bersangkutan, setelah dihubungkan dengan segi-segi yang berkaitan dengannya, misalnya latar belakang terjadinya, tetap menuntut pemahaman sesuai dengan apa yang tertulis dalam teks hadis. Demikian pula halnya dengan pemahaman dan penerapan hadis secara kontekstual, dilakukan bila "di balik" teks suatu hadis terdapat petunjuk kuat yang mengharuskan hadis yang bersangkutan dipahami dan diterapkan tidak sebagaimana maknanya yang tersurat (tekstual). ${ }^{37}$ Dengan melihat bentuk matn hadis, dapat saja diketahui bahwa hadis tersebut dapat berupa; jämi' al-kalim (ungkapan yang singkat namun padat makna), tamtsìl (perumpamaan), ramzi (bahasa simbolik), bahasa percakapan, ungkapan analogi (qiyäì), dan lain-lain.

Untuk melihat sejauh mana keterkaitan hal-hal yang dilakukan Nabi saw. dengan fungsi beliau ketika hal-hal itu dilakukan, menurut Syuhudi Ismail dapat dikaji dengan melihat kandungan hadis itu sendiri. Hadis-hadis yang

${ }^{37}$ Lihat lebih lanjut uraian M. Syuhudi Ismail, Pemahaman Hadis Nabi Secara Tekstual \& Kontekstual; Telaab Ma'ani Hadis Tentang Ajaran Islam yang Universal, Temporal \& Lokal, [Pidato Pengukuhan Guru Besar], (Makasar: IAIN Alaudin Ujung Pandang, 1994), h. 2-3. 
berhubungan dengan fungsi Nabi sebagai Rasulullah dapat dilihat dari berbagai penjelasan beliau tentang kandungan al-Qur'an, pelaksanaan ibadah, dan penetapan hukum halal-haramnya sesuatu. Untuk hadis yang dikemukakan Nabi dalam kapasitasnya sebagai seorang rasul, ulama menyatakan kesepakatan tentang wajib mematuhinya. Untuk hadis yang dikemukakan dalam kapasitas Nabi saw. sebagai kepala negara dan pemimpin masyarakat seperti pengiriman angkatan perang, kalangan ulama ada menyatakan bahwa hal itu tidak menjadi ketentuan syariat yang bersifat umum.

Dari sinilah kemudian Mahmūd Syaltūt membagi hadis atau sunnah, dalam dua klasifikasi; 1) sunnah tasyrïiyyah, yaitu sunnah yang mengandung unsur tasyri [yang umat Islam diperintahkan untuk mengikuti dan melaksanakannya], baik dalam bentuk qawliyyah, fi'liyyah, maupun taqririyyah; 2) sunnah ghayr tasyri'iyyah, yaitu sunnah yang tidak mengandung unsur tasyri' dan taklif, yang hanya berkaitan dengan urusan manusiawi, baik yang sifatnya sebagai kebutuhan kemanusiaan, seperti makan dan minum; yang sifatnya eksperimental dan kebiasaan pribadi atau sosial, seperti tentang pertanian dan kedokteran; maupun yang sifatnya kecakapan pribadi sebagai wujud interaksi dengan kondisi tertentu, seperti pembagian pasukan ke medan pertempuran, dan hal-hal lain yang dasarnya kondisi dan keadaan tertentu. ${ }^{38}$

Hal yang senada juga diungkapkan oleh Muh. Zuhri, bahwa dalam melakukan pembacaan atau pemahaman ulang terhadap hadis secara komprehensif, perlu dilihat dahulu kedudukan hadis terhadap al-Qur'an. Posisi hadis dalam hal ini untuk menjelaskan dan menjabarkan kandungan al-Qur'an yang masih global. Ketika al-Qur'an memiliki muatan yang begitu kompleks, maka hadis pun harus menyesuaikannya. Menurut Muh. Zuhri, hadis

${ }^{38}$ Menurut Syaltūt, sunnah tasyri̊iyyah ini terbagi lagi menjadi dua; pertama, yang sifatnya universal dan eternal [tasyrì 'ám], yang berlaku untuk seluruh manusia hingga hari kiamat. Sunnah ini disampaikan Nabi Muhammad saw. dalam bentuk tabligh, dalam kapasitas beliau sebagai Rasul, seperti penjelasan bentuk praktis ibadah yang diperintahkan al-Qur'an, halalharam, masalah-masalah akidah, akhlak atau masalah-masalah lainnya yang relevan. Kedua, yang sifatnya lokal-temporal, yang khusus bagi suatu kondisi atau keadaan tertentu [tasyrī khäsh]. Sunnah ini terbagi dalam dua bentuk; a) yang disampaikan Nabi saw. dalam kapasitasnya sebagai seorang imam dan pemimpin umum kaum Muslimin, seperti mengirim pasukan perang, dan hal-hal lain yang sifatnya merupakan imämah dan keperluan umum demi kemaslahatan umat; b) yang dilakukan Nabi Muhammad saw. sebagai tindakan pengadilan $(q a d h \vec{a})$. Sunnah model ini pun sama seperti model sebelumnya, bukan sebagai tasyrì umum. Maka, seseorang tidak boleh mengerjakan sesuatu dengan alasan hal itu sebagai keputusan Nabi saw. yang telah memberinya suatu hukum yang pasti. Selanjutnya lihat Mahmūd Syaltūt, alIsläm; 'Aqìdah wa Syarìah, (Kairo: Dār al-Syurūq, 2001), cet.18, h. 499-501. 
setidaknya memiliki muatan-muatan berikut: pertama, informasi gaib dan akidah (bersifat dogmatik); kedua, norma-norma ritual dan sosial; ketiga, perilaku sebagai manusia biasa; dan keempat, gagasan menatap masa depan.

Dengan kerangka ini akan dapat dipilah teks hadis yang harus dipahami apa adanya, dan teks hadis yang memberi keleluasaan dalam 'berijtihad'. Hadishadis yang bermuatan informasi gaib dan akidah yang bersifat dogmatik, nampaknya tidak dapat memberi 'banyak gerak' dalam berijtihad karena kebenarannya tidak dapat diukur dengan penalaran kreatif. Hadis-hadis tentang kiamat, malaikat, alam kubur, surga, neraka, tidak bisa dirasionalisasikan, harus dipercaya atau ditolak. Hal inilah yang nampaknya menjadi dasar pertimbangan mengapa dalam aspek gaib dan akidah diperlukan dalil yang mutawätir, karena ia bersifat supra rasional dan universal, tidak terikat oleh waktu dan situasi. Begitu pula hadis-hadis tentang ritual ibadah seperti salat, puasa dan haji, meskipun dalam beberapa hal tidak seketat dogma akidah. Kendati peluang kritis terhadap ajaran ritual itu sempit, tetapi aktualisasi ritual yang melibatkan urusan duniawi, maka ada elemen-elemen hadis yang dapat dipertimbangkan. ${ }^{39}$

Berbeda dengan hadis yang memuat norma kemanusiaan, bahwa situasi selalu mendorong munculnya sebuah norma. Perbedaan situasi akan mempengaruhi norma. Hadis-hadis yang bermuatan hukum sosial lebih memberi kelonggaran berkreasi karena ia berbicara tentang gejala sosial, yang ukuran kebenarannya mudah diamati berdasarkan kebutuhan sosial itu sendiri. Terlebih hadis-hadis yang berbicara dalam kapasitas Rasulullah sebagai manusia biasa, lebih mudah lagi dilihat konteksnya kemudian dirasionalisasikan. Kemudian sebagai pembawa agama, Rasulullah tentu memiliki obsesi agar pengikutnya menjadi masyarakat teladan dengan ciri utama rajin, setia, rasional, toleran, dan lainnya yang membawa kemajuan yang damai dan sejahtera. Hadis yang berupa gagasan dan cita-cita diperkirakan memberi keleluasaan dalam aktualisasi. Setidaknya, ajaran moralnya tidak ditawar. ${ }^{40}$

Dengan demikian, hadis-hadis yang berkaitan dengan politik, sosial, ekonomi, dan budaya merupakan celah untuk dapat dilakukan kajian yang mendalam sekaligus perlunya pembaruan penafsiran, pemahaman dan pemaknaan yang tetap sesuai dengan ruh dan jiwa keislaman terhadap khazanah literatur hadis, mengingat situasi dan pranata sosial, ekonomi, budaya

${ }^{39}$ Muh. Zuhri, Telaah Matan Hadis; sebuah Tawaran Metodologis, (Yogyakarta: LESFI, 2003), h. 50-51.

${ }^{40}$ Muh. Zuhri, Telaah Matan Hadis, h. 52. 
dan politik antara era pembukuan hadis dan era global sekarang sungguh sangat jauh berbeda.

\section{Menggagas Studi Hadis dalam Wacana Integrasi Ilmu}

Seperti yang diungkap sebelumnya, bahwa dalam hadis ditemukan berbagai fakta historis mengenai bagaimana ajaran-ajaran Islam yang diwahyukan oleh Allah swt., yang kemudian diterjemahkan dalam kehidupan nyata oleh Nabi Muhammad saw. Sebagai suatu tindakan Nabi saw. yang dimaksudkan untuk membumikan ajaran Islam dalam dunia nyata (rabmah li al'álamin), maka hadis tidak bisa mengelak dari dinamika sosial yang terjadi. Bahkan tidak jarang sebuah hadis menjadi ajang tarik menarik antara realitas sosial saat itu dan norma ideal, yang biasanya berakhir dengan suatu kompromi ajaran tertentu, meskipun semuanya masih dalam bingkai wahyu. Hampir persoalan yang muncul dalam kehidupan Nabi saw. terungkap dalam hadis. Sepeninggal Nabi saw. hadis tidak bertambah jumlahnya, sementara problem yang dihadapi oleh umat Islam terus berkembang sesuai dengan perkembangan zaman. Itulah sebabnya, dalam memahami hadis diperlukan metode pemahaman yang tepat melalui pendekatan komprehensif, baik tekstual maupun kontekstual dengan berbagai bentuknya. ${ }^{41}$

Oleh karena itu, studi hadis pun nampaknya perlu mendapatkan pencerahan metodologi dan perubahan paradigma keilmuan. Hadis, yang selama ini dipahami sebagai ucapan, perbuatan, dan ketentuan Nabi saw. adalah bagian yang tidak terpisahkan, -meminjam istilah Fazlur Rahman-, a living tradition (tradisi yang hidup atau al-Sunnah) ${ }^{42}$ di era kenabian selama kurang lebih 23 tahun berubah menjadi a literary tradition (tradisi tertulis) pada abad ke2 dan ke-3 H. dalam kitab-kitab kumpulan hadis. Tanpa disadari umat Islam, telah terjadi perubahan yang mendasar dari tradisi 'lisan' yang hidup, longgar, dan fleksibel menjadi tradisi 'tertulis', beku, kaku atau baku.

Dalam sejarah pembukuan hadis yang bersifat 'tertulis', sesungguhnya umat Islam saat itu 'dipaksa' oleh situasi yang mengitarinya, yaitu kelangkaan sahabat, tabi'in, dan tabi' al-tabi'in yang mengetahui secara persis bagaimana cara praktik hidup, ibadah, dan perilaku Nabi saw., dan maraknya hadis-hadis palsu yang dibuat oleh generasi yang hidup setelah Nabi saw. Situasi seperti ini

${ }^{41}$ Said Agil Husein Munawwar, "Metode Pemahaman Hadis; Kemungkinan Pendekatan Historis dan Antropologis" dalam Yunahar Ilyas dan M. Mas'udi (ed.), Pengembangan Pemikiran terhadap Hadis, (Yogyakarta: LPPI, 1996), h. 174.

${ }^{42}$ Lihat uraiannya dalam Fazlur Rahman, Islamic Methodology in History, (Pakistan: Islamic Research Institute, 1984). 
membuat para ilmuan muslim berupaya keras untuk menyeleksi hadis-hadis yang berasal dari Nabi dan yang bukan. Kemunculan ilmu-ilmu hadis, semisal

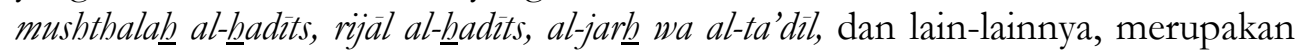
bentuk intervensi keilmuan para ilmuan hadis melalui metodologi yang digunakan untuk menentukan hadis yang sahih dan yang tidak sahih, dan begitu seterusnya. Dengan demikian, sebenarnya ada proses panjang yang bersifat historis dalam era tadwin yang seringkali dilupakan umat Islam disebabkan karena maksud baik mereka untuk segera mengamalkan apa yang dibaca dan didengar, sehingga kurang begitu peduli dengan proses dan asal usul munculnya sebuah hadis. ${ }^{43}$ Oleh karena itu, pengkajian ulang terhadap 'ulüm al-

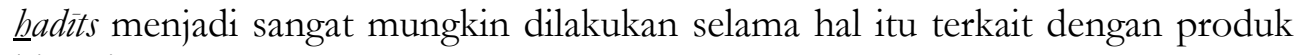
historis.

Tantangan kultural dan sosiologis yang tengah dihadapi oleh umat Islam saat ini berbeda dengan tantangan yang pernah dihadapi oleh umat Islam pada abad-abad yang silam, atau lebih ketika Ibn al-Shalāh (w. 643 H.), alZarkasyī (w. 794 H.), al-Suyūthī (w. 911 H.) menyusun karya-karya mereka dalam studi hadis. Tantangan yang menghadang mereka pada saat itu adalah bagaimana mempertahankan memori kultural bangsa, peradaban, dan pemikirannya dalam menghadapi serbuan Pasukan Salib dari Barat. Karenanya, karya-karya di bidang ilmu-ilmu al-Qur'an dan ilmu-ilmu Hadis dicermati sebagai upaya menghimpun aneka ragam tradisi ke dalam wilayah "teks" keagamaan, dan sebagai upaya untuk mempermudah agar dapat dijangkau oleh pembaca dan pencari ilmu. Langkah itu pada dasarnya merupakan respon kultural terhadap situasi yang mengharuskan nalar Arab menarik diri ke dalam, berlindung dalam wilayah ilmu "teks" dan berkonsentrasi pada kebudayaan dan pemikiran sendiri untuk melindungi dan mempertahankan kebudayaan dari kemusnahan dan kehancuran. ${ }^{44}$

Kini tantangan yang dihadapi oleh umat Islam di abad modern sudah berubah. Karenanya, pendekatan yang terlalu terpusat pada "teks" (tekstual) dalam memahami hadis tidak lagi memadai dan perlu diperkaya dengan pendekatan kontekstual atau interdisipliner yang melibatkan seperangkat disiplin ilmu lainnya, seperti ilmu-ilmu sosial dan humaniora. Dalam hal ini, peminjaman, modifikasi, maupun adaptasi unsur informasi dan unsur metodologi oleh suatu disiplin ilmu dari disiplin ilmu yang lain merupakan hal

\footnotetext{
${ }^{43}$ M. Amin Abdullah, "al-Takwil al-'Ilmiy" dalam Islamic Studies di Perguruan Tinggi; Pendekatan Integratif-Interkonektif, (Yogyakarta: Pustaka Pelajar, 2006).

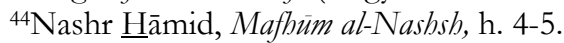


yang wajar. Memang suatu disiplin ilmu memiliki otonomi di dalam dirinya. Namun, karena gejala yang dideskripsikan dan dijelaskan olehnya merupakan satu kesatuan yang kompleks, serta tingkat perkembangan dan kemampuan disiplin ilmu itu bervariasi, maka disiplin ilmu itu tidak dapat melepaskan diri dari bantuan dan kerja sama dengan disiplin ilmu lainnya. Apalagi, jika gejala kehidupan itu akan dijelaskan secara komprehensif, maka terjadi adhesi, kohesi, bahkan integrasi antar disiplin ilmu. Integrasi dari berbagai disiplin ilmu itu, kemudian dikenal dengan pendekatan interdisipliner (antardisiplin) dan multidisipliner (multi- disiplin). Pendekatan interdisipliner merupakan penggabungan unsur informasi dan unsur metodologi dari dua atau lebih disiplin ilmu dalam satu program atau kegiatan studi menurut disiplin ilmu masing-masing, kemudian digabungkan secara eksternal sebagai satu kesatuan penyelenggaraan studi. ${ }^{45}$

Kalangan ulama terdahulu telah menerapkan pendekatan interdisipliner dalam memahami hadis, dengan menggunakan perangkat/ilmu keislaman yang berkembang saat itu seperti ilmu fikih, usul fikih, kalam, tasawuf, bahasa Arab, dan ilmu-ilmu lainnya. Pendekatan interdisipliner dalam studi hadis menggunakan perangkat ilmu-ilmu keislaman tradisional juga dilakukan oleh sejumlah ulama hadis kontemporer, semisal Muhammad al-Ghazālī dalam karyanya yang monumental, al-Sunnah al-Nawabiyyah bayn Abl al-Fiqh wa Abl alHadits. Dalam karyanya itu, al-Ghazālī berusaha mempertemukan antara disiplin hadis dan fikih dalam membahas sejumlah hadis-hadis tematis, misalnya tentang perempuan, nyanyian, etika makan, minum dan berpakaian, takdir dan fatalisme, serta masalah lainnya. ${ }^{46}$ Pendekatan yang ditawarkan oleh al-Ghazālī ini tentunya menjadi menarik dan menantang, sehingga bukunya memperoleh sambutan publik yang luar biasa.

\section{Penutup}

Sebagai catatan akhir dari tulisan ini, dapat dinyatakan bahwa kemunculan sejumlah pemikir muslim kontemporer semisal Fazlur Rahman, 'Ābid al-Jābirī, Nashr H̄āmid Abū Zayd, Mohammed Arkoun, Fatima Mernissi, Riffat Hassan, dan tokoh-tokoh terkemuka lainnya, telah memberikan

${ }^{45}$ Saifuddin, Pengembangan Studi Hadis, h. 4.

${ }^{46}$ Lihat lebih lanjut dalam Muhammad al-Ghazāin, al-Sunnah an-Nabawiyyah bayn Abl alFiqh wa Abl al-ㅌadits, (Kairo: Dār al-Syurūq, 1989). Buku aslinya ini telah diterjemahkan dalam versi bahasa Indonesia oleh Muhammad al-Baqir dengan judul Studi Kritis atas Hadis Nabi saw.; antara Pemahaman Tekstual dan Kontekstual, (Bandung: Mizan, 1996). 
penyegaran dan sumbangan pemikiran orisinil (contribution of knowledge) terhadap pengembangan studi Islam, dalam karya-karya mereka, baik dalam tataran metodologi maupun materi keislaman, dan berdampak besar terhadap kajiankajian tafsir dan hadis yang selama ini melesu dan bahkan mengalami stagnasi metodologis.

Di satu sisi, pemikiran-pemikiran para tokoh tersebut sudah selayaknya diapresiasi sebagai dinamika yang memperkaya khazanah intelektual Islam sebab bagaimanapun kemunculan pemikiran mereka merupakan respon positif terhadap perkembangan dan tantangan zaman global yang semakin kompleks. Berkat jasa mereka, studi Islam menjadi isu penting yang menjadi perhatian dunia, terlebih bagi kalangan oreintalis Barat dan pemerhati serta pengkaji Islam lainnya. Pengayaan metodologi, pengembangan wacana-wacana keilmuan Islam yang lebih kontekstual, menjadi karakteristik pemikiran-pemikiran tersebut. Kini, kajian-kajian tafsir maupun hadis sudah mulai bangun dari 'tidur panjangnya'. Pemaknaan, penafsiran dan pemahaman terhadap teks-teks alQur'an dan hadis yang semula terkesan kaku dan rigid menjadi lebih membumi dan responsif terhadap tuntutan zaman.

Namun di sisi lain, pemikiran-pemikiran tersebut tentunya harus dikritisi dan tidak mesti 'ditelan seratus persen' sebab bagaimanapun ia merupakan produk manusia yang tidak luput dari keterbatasan dan ketidaksempurnaan. Jika ditelusuri sejarah perkembangan paradigma-paradigma dalam ilmu sosial, sebagaimana dijelaskan George Ritzer, ${ }^{47}$ bahwa munculnya setiap paradigma adalah karena kritik terhadap keterbatasan paradigma yang telah ditawarkan dalam memahami realitas. Paradigma definisi sosial (social definition paradigm), misalnya, adalah kritik atas paradigma fakta sosial (social fact paradigm). Akhirnya, setiap paradigma memiliki keterbatasan, di samping keunggulannya, dalam membatasi realitas, karena realitas keagamaan adalah realitas yang kompleks. Kesimpulannya, Ritzer menyarankan paradigma integratif, yaitu paradigma yang menggabungkan paradigma fakta sosial, definisi sosial, dan perilaku sosial.

Sebenarnya, hal yang sama juga terjadi pada pendekatan-pendekatan dalam kajian Islam, khususnya kajian tafsir dan hadis. Harus dibangun anggapan bahwa tidak ada pendekatan tanpa keterbatasan, sebagaimana setiap pendekatan juga memiliki keunggulan. Jika dilakukan over-view pendekatanpendekatan dalam mengkaji Islam, tentu akan sampai pada kesimpulan tidak

${ }^{47}$ Lihat dalam karyanya George Ritzer, Sociology: A Multiple Paradigm Science, (Boston: Allyn and Bacon, Inc., 1980). 
ada pendekatan kajian Islam yang sempurna dan final, karena realitas Islam yang begitu kompleks. Amin Abdullah, pernah menyatakan bahwa 'finalitas' tidak memberikan kesempatan munculnya new possibilities yang barangkali lebih kondusif untuk menjawab persoalan-persoalan sosial-keagamaan kontemporer. Finalitas dan eksklusifitas sama sekali menepikan kenyataan bahwa keberagamaan Islam sungguh bukanlah peristiwa yang 'sekali jadi'. Keberagamaan adalah proses panjang (on going process of religiosity) menuju kematangan dan kedewasaan sikap beragama. ${ }^{48}$

Oleh karena itu, kritik terhadap pengembangan metodologis dalam studi hadis menjadi suatu keniscayaan. Dalam hal ini, sebagian besar tawaran metodologis yang dikemukakan oleh para pemikir muslim kontemporer masih berada dalam tataran 'wacana' atau bersifat teoritis, belum banyak yang bersifat aplikatif. Di sinilah sebenarnya permasalahan dekonstruksi atau rekonstruksi pemahaman terhadap hadis dimulai. Inilah yang akan menjadi tantangan terbesar bagi para generasi muslim untuk mengintegrasikan berbagai disiplin ilmu dalam studi hadis. Namun demikian, tidak semua pendekatan keilmuan tersebut dapat diaplikasikan secara meyakinkan dalam seluruh hadis yang ada, tetapi untuk mencapai ke arah tersebut, masih memerlukan identifikasi, klasifikasi, dan telaah ulang terhadap perkembangan pemikiran dan pemahaman terhadap hadis []

\section{DAFTAR PUSTAKA}

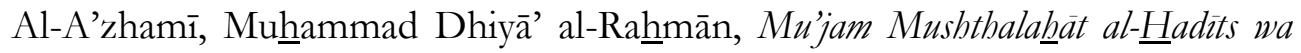
Lathäàif al-Asānid, (Riyādh: Maktabah Adhwā' al-Salaf, 1999).

Al-A'zhamī, Muhammad Mushthafā, Manhaj an-Naqd 'ind al-Mubadditsinn, (Riyādh: Syirkah al-Thibā'ah al-Su'ūdiyyah, 1982)

Abū Zayd, Nashr Hāāmid, Mafhūm al-Nash; Dirāsah fì 'Ulūm al-Qur'ān, diterjemahkan oleh Khairon Nahdliyyin dengan judul Tekstualitas alQur'an; Kritik terhadap Ulumul Qur'an, (Yogyakarta: LKiS, 2000).

Al-Adhlabī, Shalah al-Dīn ibn Aḥmad, Manhaj Naqd al-Matn, (Beirut: Dār alĀfāq al-Jadīiah, 1983).

Ali, Nizar, Memahami Hadis Nabi; Metode dan Pendekatan, (Yogyakarta: CESaD YPI al-Rahmah, 2001).

${ }^{48}$ M. Amin Abdullah, "al-Takwil al-'Ilmiy" dalam Islamic Studies, h. 224. 


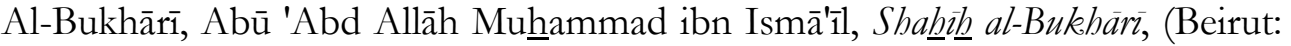
Dār al-Fikr, t.th.).

Fazlur Rahman, Islamic Methodology in History, (Pakistan: Islamic Research Institute, 1984).

Al-Ghazāin, Muhammad, al-Sunnab an-Nabawiyyah bayn Abl al-Fiqh wa Abl al$\underline{\text { H}}$ adits, diterjemahkan oleh Muhammad al-Baqir dengan judul Studi Kritis atas Hadis Nabi saw.; antara Pemahaman Tekstual dan Kontekstual, (Bandung: Mizan, 1996).

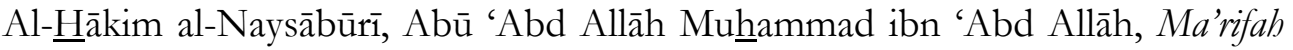

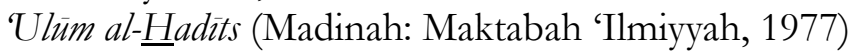

Hodgson, Marshall G.S., The Venture of Islam; Conscience and History in World Civilization, (Chicago: The University of Chicago Press, 1974).

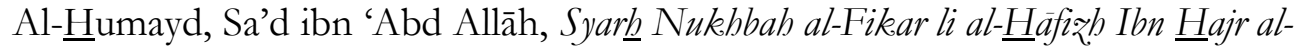
'Asqalāni, (t.tp.: Dār 'Ulūm al-Sunnah, t.th.).

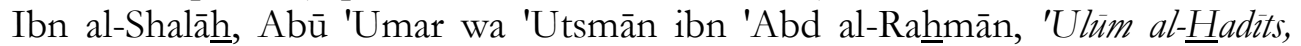
(Beirut: Dār al-Fikr, 1986)

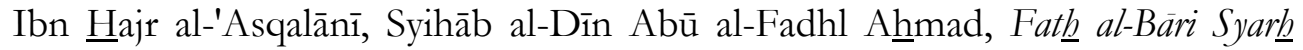
Shabzîh al-Bukhārì, (Beirut: Dār al-Fikr, 1992).

Ibn Katsīr, Abū al-Fidā' Ismā̄̄l ibn 'Umar al-Quraysȳ̄ al-Dimasyqū, Ikhtishār

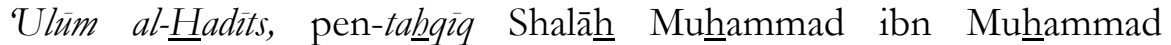
'Uwaydhah, (Beirut: Dār al-Kutub al-'Ilmiyah, 1989).

'Itr, Nūr ad-Dīn, Lamabāat Müjaz̧ah fi Manāhij al-Mubadditsin al-'Āmmah fí alRiwaàah wa al-Tashniff, (Damaskus: Dār al-Farfūr, 1999).

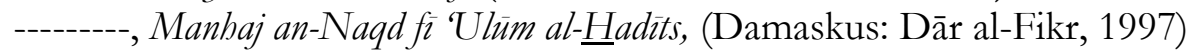

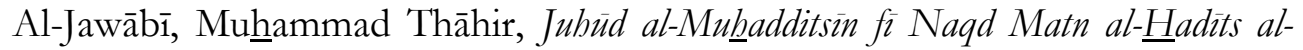
Nabawî al-Syarif, (Tunisia: Mu'assasah 'Abd al-Karīm ibn 'Abd Allāh, t.th.)

Al-Khathīb al-Bughdādī, Abū Bakr Aḥmad ibn 'Alī ibn Tsābit, al-Kifāyah fì Tlm al-Riwayah, (Beirut: Dār al-Kutub al-'Ilmiyyah, 1988)

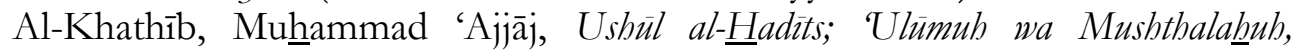
(Beirut: Dār al-Fikr,1989).

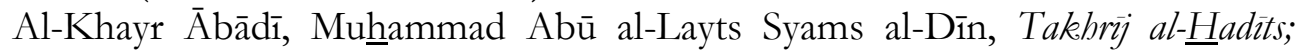
Nasy'atuh wa Manhajizyyatuh, (Malaysia: al-Jāmi'ah al-Islāmiyyah alĀlamiyyah, 1997).

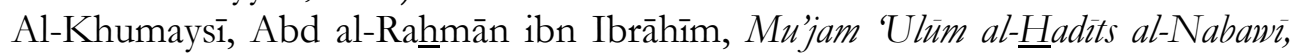
(Jeddah: Dār al-Andalus al-Khadhrā', 1419 H.) 
M. Amin, Abdullah, Islamic Studies di Perguruan Tinggi; Pendekatan IntegratifInterkonektif, (Yogyakarta: Pustaka Pelajar, 2006).

M. Syuhudi, Ismail, Kaedah Kesahihan Sanad; Telaah Kritis dan Tinjanan dengan Pendekatan Ilmu Sejarah, (Jakarta: Bulan Bintang, 1995).

--, Metodologi Penelitian Hadis Nabi, (Jakarta: Bulan Bintang, 1992).

---------, Pemahaman Hadis Nabi Secara Tekstual \& Kontekstual; Telaah Ma'ani Hadis Tentang Ajaran Islam yang Universal, Temporal \& Lokal, Pidato Pengukuhan Guru Besar], (Makasar: IAIN Alaudin Ujung Pandang, 1994).

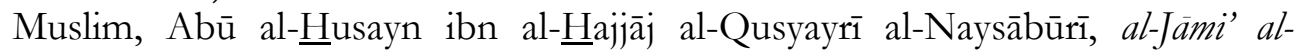
Shabizh, (Beirut: Dār al-Fikr, t.th.)

Al-Qardhawī, Yūsuf, Kayf Nata'ämal ma' al-Sunnah al-Nabawiyyah; Ma'älim wa Dhawabith, (USA: al-Ma'had al-'Ālamī li al-Fikr al-Islāmī, 1992).

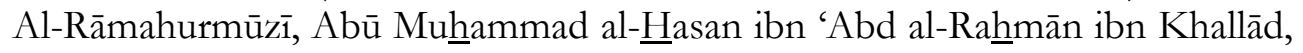
al-Muhaddits al-Fäshil bayn al-Rāwñ wa al-Wä̀', (Beirut: Dār al-Fikr, 1984)

Ritzer, George, Sociology: A Multiple Paradigm Science, (Boston: Allyn and Bacon, Inc., 1980).

Sābiq, Sayyid, Fiqh al-Sunnah, (Semarang: Toha Putra, t.th.), vol. 3, h. 315.

Said Agil, Husein Munawwar, "Metode Pemahaman Hadis; Kemungkinan Pendekatan Historis dan Antropologis" dalam Yunahar Ilyas dan M. Mas'udi (ed.), Pengembangan Pemikiran terhadap Hadis, (Yogyakarta: LPPI, 1996)..

Saifuddin, Pengembangan Studi Hadis Melalui Pendekatan Interdisipliner, makalah Workshop Keagamaan Ilmu-Ilmu Keushuluddinan tanggal 22 s.d. 25 Agustus 2005 (Banjarmasin: Fakultas Ushuluddin IAIN Antasari Banjarmasin, 2005).

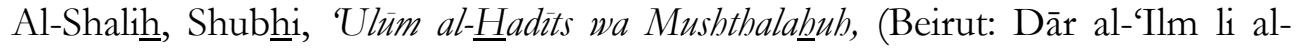
Malāyīn, 1988).

Al-Suyūthī, Jalāl al-Dīn 'Abd al-Raḥmān ibn Abū Bakr, Tadrìb al-Rāwñ fì Syarh

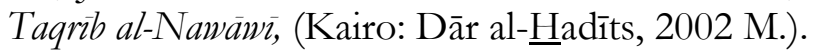

Al-Syāfi'̄̄, Muhammad ibn Idrīs, al-Risālah, (Beirut: Dār al-Kutub al-'Ilmiyyah, t.th.)

Syaltūt, Mahnūud, al-Isläm; 'Aqìdah wa Syarìah, (Kairo: Dār al-Syurūq, 2001).

Al-Syawkānī, Muhammad ibn 'Alī ibn Muhammad, Nayl al-Awthār, (Mesir: Mushthafā al-Bābī al- $\underline{H} a l a b \overline{1}$, t.th.).

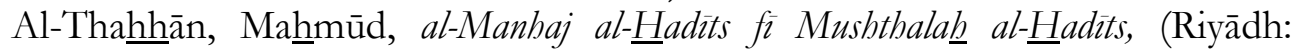
Maktabah al-Ma'ārif, 2004). 


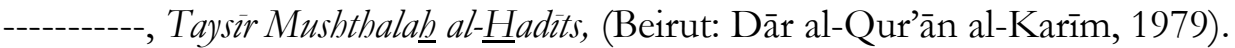

---------, Usbūl al-Takbrìj wa Dirāsah al-Asānìd, (Riyādh: Maktabah al-Ma'ärif, 1996).

Zuhri, Muh., Telaah Matan Hadis; sebuah Tawaran Metodologis, (Yogyakarta: LESFI, 2003). 